\title{
SUITABILITY OF COMBINED SEWERS FOR THE INSTALLATION OF HEAT EXCHANGERS
}

\author{
MOŻLIWOŚĆ MONTAŻU WYMIENNIKÓW CIEPŁA \\ W PRZEWODACH KANALIZACJI OGÓLNOSPŁAWNEJ
}

\begin{abstract}
The present paper deals with the classification of the suitability of combined sewers for the installation of heat exchangers and with assessment of the theoretical potential of wastewater in the sewer system for heating of buildings. A classification scheme involving criteria like theoretically available heat, sewer diameter, number of the heat exchanger parallel modules in the sewer cross-section, hydraulic conditions (hydraulic capacity of the sewer, pressurized flow), and potential fouling by biofilm growth was developed. First, individual sewers in the pilot catchment were assessed based on monitoring the flow characteristics and wastewater temperatures and on pipe flow modelling. Second, connectivity of the suitable and partly suitable sewers was examined with respect to the length necessary for the installation of the heat exchanger with the minimum required power of $100 \mathrm{~kW}$. For the continuous sewer sections, the maximum potential power was calculated. The presented approach is generally applicable, however, for other heat exchanger types and other climatic and economic conditions, values of the suitability criteria for the heat exchanger installation must be adapted.
\end{abstract}

Keywords: heat exchanger, heat recovery, sewer system, urban drainage masterplan, wastewater

\section{Introduction}

Many countries take aim at increasing use of secondary sources of energy, including heat recovery. A reason for that is strengthening the energetic self-sufficiency and protection of environment impacted by fossil sources exploitation. One of effective solutions is using thermal energy of warm wastewater as a secondary energy source.

This solution would also contribute to the reduction of energy demand in the urban water cycle (UWC). According to the articles $[1,2]$ in big cities between 7 and $10 \%$ of total energy spent in the whole UWC is lost in the sewer systems and the primary energy consumption for collection and transportation of wastewater and other water equals $105 \mathrm{MJ} / \mathrm{cap} /$ year in the Netherlands, $530 \mathrm{MJ} / \mathrm{cap} /$ year in USA, $380 \mathrm{MJ} / \mathrm{cap} /$ year in Toronto

\footnotetext{
${ }^{1}$ Faculty of Civil Engineering, Czech Technical University in Prague, Thakurova 7, 16629 Prague, Czech Republic, phone +420 22435 5412, email: stransky@fsv.cvut.cz

${ }^{2}$ Faculty of Environmental Engineering, Lublin University of Technology, ul. Nadbystrzycka 40B, 20-618 Lublin, Poland, phone +48 815384322

* Corresponding author: stransky@fsv.cvut.cz
} 
and $74 \mathrm{MJ} / \mathrm{cap} / \mathrm{year}$ in Sydney. A lot of this energy is in form of heat from water heating in households and from industrial processes [2-4].

In households, hot water is necessary for hygiene, washing or food preparation and its consumption is more than $80 \%$ of all water use resulting in average wastewater temperature $28^{\circ} \mathrm{C}[5,6]$. Thus, heat may be recovered from domestic wastewater production in small scale systems [7-10].

In the sewer system, wastewater temperature results both from industrial and domestic water usage and exhibits a stable temperature of $10-20^{\circ} \mathrm{C}$ all the year round. Due to the heat dissipation and interaction with the ground, the highest temperature of wastewater is usually in the upper part of the sewer system $[2,11]$. To utilize wastewater energy heat exchangers coupled with heat pumps can be installed in the sewer system and used for hot water production, heating the buildings or for the combination of winter heating and summer cooling [12]. These heat exchangers can be shell and tube heat exchangers, spiral tube heat exchangers or plate heat exchangers mounted on pre-built pipes or pits which can be placed in the existing networks [2].

Over 500 wastewater heat pumps with thermal ratings ranging between 10 and $20 \mathrm{MW}$ are in operation world-wide, especially in Switzerland and Germany.

According to the article [13], the first wastewater heat recovery system applying heat pumps was installed in 1975 in Zurich, Switzerland. One of the largest systems is located in Oslo, Norway and delivers 288 TJ of energy per year [2]. Another system of heat recovery from sewage is in Vancouver, Canada, where heat is received from the sewer of housing complex using heat pit exchangers. They are equipped with special devices to remove solids from the sewage. It covers $70 \%$ of heat demand for about 16,000 inhabitants [2]. An interesting example of designing of wastewater systems together with heat recovery in industrial conditions is presented in the following paper [14], where a parallel design of the wastewater network and of the heat recovery network and cooperation between the two of them is assumed. An example of utilization of wastewater heat in Polish conditions is presented in the article [17]. In the Czech Republic, wastewater as an energy source for the heat pumps has so far been neglected. The main arguments are the long payback period due to the high acquisition costs and possible impacts of the decrease of wastewater temperature on the wastewater treatment efficiency and operation costs.

Extensive heat recovery from the sewer system accompanied by a significant decrease of the wastewater temperature may generate problems for the biological processes at the wastewater treatment plant (WWTP). Low temperatures endanger especially nitrogen removal during nitrification-denitrification [16]. According to the article [2] the lowest possible temperature of wastewater delivered to WWTP should be $12^{\circ} \mathrm{C}$. Apart from the impacts on the WWTP processes, the decrease of temperature also affects processes of transformation and biodegradation of pollutants in sewer systems [17-19], which may result in higher loads of pollutants entering the treatment plants. Thus, the wastewater temperature decrease strongly influences the potential of installation of heat exchangers in the sewers. Another significant problem related to the in-sewer heat exchanger operation is the formation of biofilms resulting to the surface fouling of the exchanger and heat transfer decrease which is described in the article [20] in a broader scale.

Therefore the project which arose in the Czech Republic is concentrated on the three aspects of the heat recovery from wastewater in the combined sewer system: 
- development of a guidance for the conceptual planning of the heat recovery from wastewater in the sewer system at the level of the whole urban catchment,

- design of a cost-efficient type of an in-sewer heat exchanger,

- development of suitable maintenance techniques in order to reduce heat exchanger fouling and related decrease of the heat recovery.

The present paper deals with the assessment of the theoretical potential of the heat recovery from the sewer system for the designed heat exchanger in the pilot catchment. The goal was to develop a classification scheme, as much objective as possible, of sewers suitability for the installation of heat exchangers and to extend the assessment of the theoretical heat recovery potential so as to cover the whole urban catchment.

\section{Materials and methods}

The assessment of the theoretical potential of the heat recovery from the wastewater in the sewer system covered the following steps:

- specification of the criteria of the sewers suitability for the installation of the heat exchangers,

- $\quad$ pilot catchment monitoring,

- re-calibration of the simulation model of the pilot catchment (dry-weather flows),

- evaluation of individual sewers (sewer reaches) in the pilot catchment based on the individual criteria as well as on their combination,

- evaluation of the whole sewer system.

\section{Suitability criteria of individual sewers for the installation of heat exchangers}

The criteria depend to a certain extent on the heat exchanger type and construction. In the framework of the project, a modular plate heat exchanger made of stainless steel was developed. The individual modules $(250 \times 1800 \times 30 \mathrm{~mm}$ in size $)$ can be connected in series and installed in parallel in the sewer. The construction of the heat exchanger facilitates also its installation in curved sections of the sewer system.

For the heat exchanger designed, the following main criteria influencing the possibility of its installation and of the amount of the heat recovered were specified:

- theoretically available heat,

- sewer diameter,

- number of the heat exchanger parallel modules in the sewer cross-section,

- hydraulic conditions,

- risk of significant heat exchanger fouling by the biofilm growth.

\section{Theoretically available heat}

Value of the theoretically available heat in the individual sewer reaches $W_{W T}[\mathrm{~kW}]$ can be calculated as:

$$
W_{W T}=c \cdot \rho \cdot Q \cdot \Delta T
$$

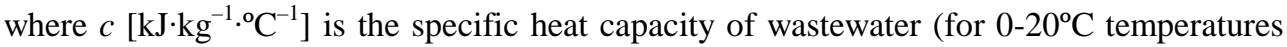
a constant value of $4.19 \mathrm{~kJ} \cdot \mathrm{kg}^{-1} \cdot{ }^{\circ} \mathrm{C}^{-1}$ can be assumed), $\rho\left[\mathrm{kg} \cdot \mathrm{dm}^{-3}\right]$ is the wastewater density (for $0-20^{\circ} \mathrm{C}$ temperatures constant value of $1 \mathrm{~kg} \cdot \mathrm{dm}^{-3}$ can be used), $Q\left[\mathrm{dm}^{3} \cdot \mathrm{s}^{-1}\right]$ is the 
wastewater discharge, and $\Delta T\left[{ }^{\circ} \mathrm{C}\right]$ is the difference between wastewater temperatures upstream $T_{1}\left[{ }^{\circ} \mathrm{C}\right]$ and downstream $T_{2}\left[{ }^{\circ} \mathrm{C}\right]$ of the heat exchanger.

It is apparent from Eq. (1), that important factors influencing the available heat are the wastewater discharge $Q$ and the exploitable temperature difference $\Delta T$.

For $Q$, the average daily discharge during the heating season (period from September, $1^{\text {st }}$ to May, $31^{\text {st }}$ ) was used. Its values in individual sewers were obtained from the simulation model calibrated for dry-weather flows.

The higher the wastewater temperature $T_{1}$ and the higher its admissible cooling, the more energy can be recovered. The values of $T_{1}$ adopted are the average daily temperatures of wastewater during the heating season expressed at a $95 \%$ lower confidence limit. The data were obtained by monitoring in end profiles of the trunk sewers of the pilot catchment. For the evaluation, the temperatures were assumed to be constant along the trunk sewer. This assumption is on the safe side [20]. The value of the minimum admissible wastewater temperature after cooling by the heat exchanger $T_{2}$ is $8^{\circ} \mathrm{C}$. It corresponds to the average daily temperatures of about $12^{\circ} \mathrm{C}$ in the pilot catchment (Table 1).

Table 1

Statistically evaluated data from monitoring of trunk sewers end profiles (for sewer system layout see Figure 2)

\begin{tabular}{|c|c|c|c|c|c|c|c|c|c|}
\hline \multicolumn{2}{|c|}{ Flow and temperature characteristics } & A & 1A & B & C & 1C & D & E \\
\hline $\mathrm{Q}$ & mean value & {$\left[\mathrm{s}^{-1}\right]$} & 60 & 26 & 58 & 61 & 27 & 65 & 31 \\
\hline \multirow{2}{*}{$\mathrm{T} 1$} & mean value & {$\left[{ }^{\circ} \mathrm{C}\right]$} & 12.9 & 13.4 & 12.1 & 14.8 & 13.7 & 14.1 & 13.8 \\
\cline { 2 - 10 } & $95 \%$ lower confidence limit & {$\left[{ }^{\circ} \mathrm{C}\right]$} & 7.6 & 9.9 & 8.6 & 10.3 & 8.9 & 10.9 & 9.6 \\
\hline
\end{tabular}

The limiting value of the available heat of $100 \mathrm{~kW}$ is based on the economic efficiency in Germany. For the Czech Republic (and the heat exchanger developed), this value will be specified by a detailed economic analysis in following stages of the project. A somewhat lower value is expected.

\section{Sewer diameter}

This criterion takes into account the possibility of an installation of the heat exchanger and its accessibility for the maintenance and biofilm removal. The limiting value is set to $800 \mathrm{~mm}$ as it is the smallest sewer diameter allowing manual installation and maintenance of the heat exchanger.

The data for the pilot catchment were obtained from the GIS of the sewer system.

\section{Number of parallel modules of the heat exchanger}

The number of the parallel modules, which can be installed in a sewer cross-section, depends on the minimum daily water depth of wastewater $H_{\min }$ and on the sewer diameter (Table 2). When more parallel modules are installed, minimally a $400 \mathrm{~mm}$ walk-through space must be ensured (Fig. 1).

To classify a sewer reach as suitable for the heat exchanger installation, at least one module must be entirely under water during the dry weather flow. Possibility of installation of two or more parallel modules increases the suitability of the sewer reach.

Necessary information was gained from the simulation model calibrated on dry-weather flows. 
Number of parallel modules of the heat exchanger for different ranges of minimum daily water depths in circular pipes

\begin{tabular}{|c|c|c|c|c|}
\hline \multirow{2}{*}{$\begin{array}{c}\text { Diameter of } \\
\text { circular pipe } \\
{[\mathbf{m m}]}\end{array}$} & \multicolumn{4}{|c|}{ No. of parallel modules of the heat exchanger } \\
\cline { 2 - 5 } & $\mathbf{0}$ & $\mathbf{1}$ & $\mathbf{2}$ & $\mathbf{4}$ \\
\hline 800 & $<50$ & $50-266$ & $267-511$ & $>511$ \\
\hline 1000 & $<45$ & $45-223$ & $224-451$ & $>451$ \\
\hline 1200 & $<43$ & $43-193$ & $194-397$ & $>397$ \\
\hline 1500 & $<40$ & $40-162$ & $163-335$ & $>335$ \\
\hline 2000 & $<37$ & $37-129$ & $130-265$ & $>265$ \\
\hline
\end{tabular}

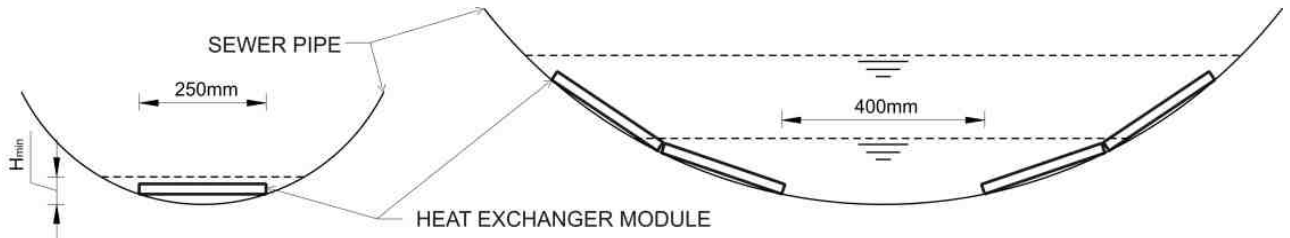

Fig. 1. Scheme of the heat exchanger installation (left: 1 module, right: 4 parallel modules)

\section{Hydraulic conditions}

Heat exchangers cannot substantially decrease the hydraulic capacity of the sewer and must not be installed in overloaded sewers. Combined sewers are traditionally designed for a design storm frequency once per 2 years. In case a sewer reach is overloaded more often, the heat exchanger installation is forbidden (with exception of backflow). When the overloading is less frequent, a decrease of the cross section area up to $5 \%$ is allowed (the developed heat exchanger decreases the cross section area by less than $2 \%$ in most cases).

The analysis of the sewer system in the pilot catchment was performed using the original simulation model calibrated for wet weather discharges for a 10-year rainfall series [21].

\section{Fouling}

In-sewer heat exchangers are subject to fouling caused by bacterial biofilms and incorporated inorganic matter [11, 22-24], which can lead to a substantial reduction of the heat transfer efficiency up to 50\% [25]. That requires the heat exchangers to be either efficiently cleaned or oversized. Both strategies bring additional costs. The amount of biofilm decreases with increasing shear stress [26-28]. Thus, sewers with high shear stress during dry weather and sewers subject to sufficient biofilm scouring during storm events generally favor the heat exchanger installation. No limiting value of the amount of biofilm is given as the occurrence of the biofilm growth is not a discriminative criterion, however, it indicates increased costs.

Potential heat exchangers installation sites in the pilot catchment were analyzed for the probability of biofilm scouring (ie sewers self-cleansing) with the help of long-term rainfall-runoff simulations for different self-cleansing criteria based on the following literature [11, 29-31] and on own observations (shear stress $2.5,7,15$ and $25 \mathrm{~N} / \mathrm{m}^{2}$ of the minimum duration of 5 and 20 minutes and frequency 1 per 2 weeks). 


\section{Classification}

Numerical values of the criteria and classification scheme of the sewers suitability for the installation of heat exchangers are presented in Table 3. The final classification is determined by the worst value of the individual criteria.

Suitability criteria of sewers for the installation of heat exchangers

\begin{tabular}{|c|c|c|c|c|}
\hline \multicolumn{2}{|c|}{ Criterion } & \multicolumn{3}{c|}{ Suitability classification } \\
\cline { 3 - 5 } & & unsuitable & partly suitable & suitable \\
\hline Theoretically available heat & {$[\mathrm{kW}]$} & $<100$ & --- & $\geq 100$ \\
\hline Sewer diameter & {$[\mathrm{mm}]$} & $<800$ & $800-1200$ & $>1200$ \\
\hline Parallel modules & {$[$ number] } & 0 & 1 & $>1$ \\
\hline Hydraulic capacity decrease & {$[\%]$} & $>5 \%$ & --- & $\leq 5 \%$ \\
\hline Pressurized flow & {$[$ frequency] } & $>1$ per 2 years & --- & $\leq 1$ per 2 years \\
\hline
\end{tabular}

\section{Evaluation of the whole sewer system}

For the whole sewer system it is decisive if the suitable and partly suitable sewers are connected so that their length is sufficient for the installation of the heat exchanger with the minimum required power of $100 \mathrm{~kW}$. If not, these sewer reaches are further classified as unsuitable. The power of the heat exchanger $P_{W T}[\mathrm{~kW}]$ can be estimated by the following equation:

$$
P_{W T}=k \cdot A_{W T} \cdot \Delta T^{*}
$$

where $k\left[\mathrm{~kW} \cdot \mathrm{m}^{-2} \cdot{ }^{\circ} \mathrm{C}^{-1}\right]$ is the heat transfer coefficient and its value taking account of fouling is assumed to be 0.60 (DWA 2009), $A_{W T}\left[\mathrm{~m}^{2}\right]$ is the heat exchanger surface area calculated as the multiple of the number of parallel modules, exchanger width $b[\mathrm{~m}]$ and length $L[\mathrm{~m}]$, and $\Delta T^{*}\left[{ }^{\circ} \mathrm{C}\right]$ is the logarithmic mean temperature difference [32] and for counter current flow of circulating fluid and wastewater can be calculated as:

$$
\Delta T^{*}=\left(\left(T_{\text {hot }}^{\text {in }}-T_{\text {cold }}^{\text {out }}\right)-\left(T_{\text {hot }}^{\text {out }}-T_{\text {cold }}^{\text {in }}\right)\right) / \ln \left(\left(T_{\text {hot }}^{\text {in }}-T_{\text {cold }}^{\text {out }}\right) /\left(T_{\text {hot }}^{\text {out }}-T_{\text {cold }}^{\text {in }}\right)\right)
$$

where $T_{\text {cold }}^{\text {in }}\left[{ }^{\circ} \mathrm{C}\right]$ is the circulating fluid temperature at the heat exchanger inlet, $T_{\text {cold }}{ }^{\text {out }}\left[{ }^{\circ} \mathrm{C}\right]$ is the circulating fluid temperature at the heat exchanger outlet, $T_{\text {hot }}{ }^{\text {in }}\left[{ }^{\circ} \mathrm{C}\right]$ is the wastewater temperature immediately upstream of the heat exchanger, $T_{\text {hot }}{ }^{\text {out }}\left[{ }^{\circ} \mathrm{C}\right]$ is the wastewater temperature immediately downstream of the heat exchanger.

In order to ensure effective functioning of the heat exchanger, $\Delta T^{*}$ should be in the range of $3-4^{\circ} \mathrm{C}[33]$ (the value of $3.5^{\circ} \mathrm{C}$ was used in calculations).

\section{Pilot catchment monitoring}

The pilot catchment is the city of Hradec Kralove, Czech Republic (90,000 inhabitants). It is drained by the combined sewer system composed of 8 trunk sewers (A, $1 \mathrm{~A}, \mathrm{~B}, 1 \mathrm{C}, \mathrm{C}, \mathrm{D}, \mathrm{E}$, and $\mathrm{F}$ ) running into the interceptor conveying the wastewater to the wastewater treatment plant (WWTP). The total length of sewers is $497 \mathrm{~km}$.

In the pilot catchment one-year monitoring (02.2013-02.2014) of wastewater discharges, wastewater and air temperatures, and of rainfall was performed. The monitoring scheme is given in Figure 2. The monitoring time steps were $6 \mathrm{~min}$ for discharges and wastewater temperatures, $1 \mathrm{~h}$ for air temperatures, and $1 \mathrm{~min}$ for rainfall. 


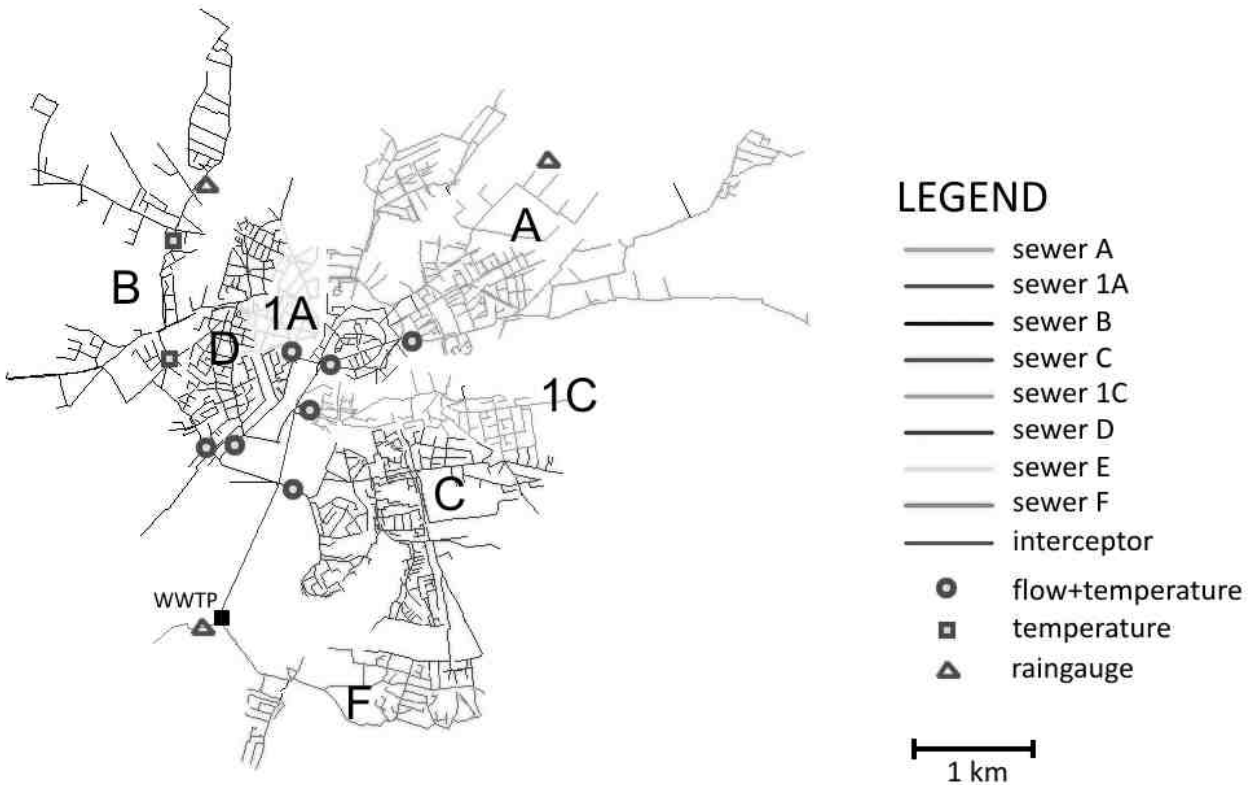

Fig. 2. Situation map of monitoring in the pilot catchment (WWTP - waste water treatment plant)

\section{Model re-calibration}

The existing sewer system simulation model created in 2005 within the Urban Drainage Masterplan in DHI software MIKE URBAN was originally calibrated focusing on wet weather flow. Re-calibration of the model for dry weather flow conditions was performed based on the data obtained from the monitoring.

\section{Results and discussion}

\section{Suitability of individual sewers for the installation of heat exchangers}

Individual criteria. Evaluation of the sewers in the pilot catchment based on individual criteria of the heat recovery potential is summarized in Table 4. Hydraulic conditions were assessed only for sewers with the theoretically available heat $\geq 100 \mathrm{~kW}$ and were not limiting in any case. The most stringent criterion was the theoretically available heat, the least stringent one was the sewer diameter. Thus, for practical reasons, it can be recommended to start the evaluation either from the most stringent or from the most easily evaluable criterion and further progress to other criteria. to the individual criteria

\begin{tabular}{|c|c|c|c|c|c|c|}
\hline \multirow{2}{*}{$\begin{array}{c}\text { Suitability } \\
\text { classification }\end{array}$} & \multicolumn{2}{|c|}{ Theoretically available heat } & \multicolumn{2}{c|}{ Sewer diameter } & \multicolumn{2}{c|}{ Parallel modules } \\
\cline { 2 - 7 } & No. of sewers & Length [m] & No. of sewers & Length [m] & No. of sewers & Length [m] \\
\hline Suitable & 182 & 10,742 & 293 & 17,920 & 25 & 1,851 \\
\hline $\begin{array}{c}\text { Partially } \\
\text { suitable }\end{array}$ & --- & --- & 611 & 37,597 & 460 & 24,597 \\
\hline
\end{tabular}


The biofilm scouring and the sewers self-cleansing probability is determined by the rainfall distribution over the year while the increased shear stress duration is of a minor importance. In the period 09-04, no sewer reaches being potential heat exchanger installation sites in the pilot catchment comply the most stringent self-cleansing criterion $\left(25 \mathrm{~N} / \mathrm{m}^{2}\right)$ and only $4 \%$ of the reaches suit the least stringent criterion $\left(2.5 \mathrm{~N} / \mathrm{m}^{2}\right)$. Thus, no self-cleansing can be counted on in the heating season (09-05). In the cooling season (06-08) up to $17 \%$ of the heat exchangers might be subject to self-cleansing, however, in case the most stringent criterion is valid, this number reduces to only $1 \%$.

Criteria combination. The evaluation of the sewers in the pilot catchment for the combination of all criteria is visualized in Figure 3. Total length of the reaches suitable for installation of the heat exchangers is $642 \mathrm{~m}$, of the partly suitable reaches $8,645 \mathrm{~m}$. The highest potential was identified in the downstream parts of the trunk sewers B, C, and D.

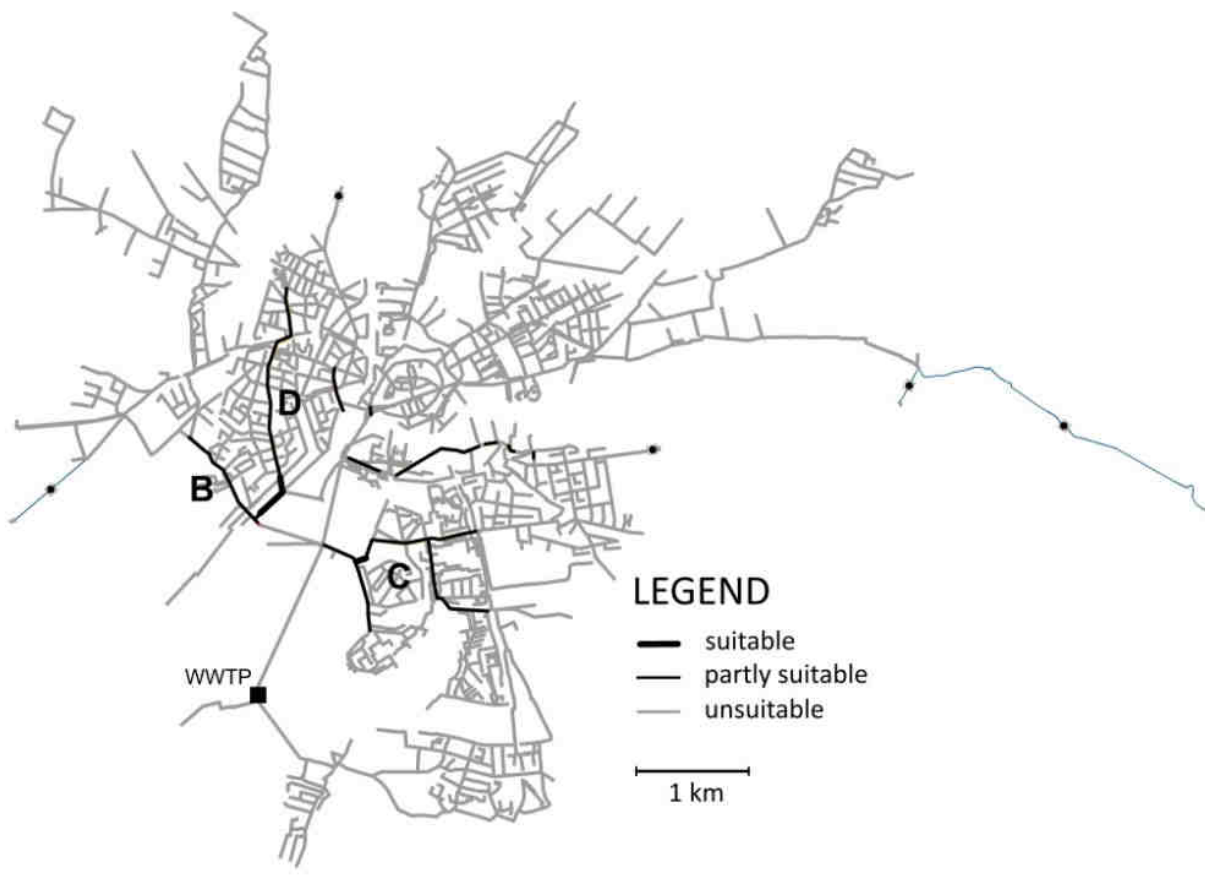

Fig. 3. Suitable and partly suitable sewers for the heat recovery in the pilot catchment

\section{Theoretical heat recovery potential of the whole sewer system}

Assessment of connectivity of the individual sewers identified as suitable or partly suitable revealed that they are connected at the trunk sewers B, C, and D whereas other trunk sewers (1A and 1C) are interrupted by short reaches of either small diameter or insufficient water depth where the heat exchangers cannot be installed. Evaluation of suitability of all continuous trunk sewers sections for the heat recovery enhanced for the estimated potential power of heat exchangers according to Eq. (2) is summarized in Table 5. The final total length of the reaches suitable for installation of the heat exchangers remained 
$642 \mathrm{~m}$, that of the partly suitable reaches decreased by $215 \mathrm{~m}$ to $8,430 \mathrm{~m}$. Trunk sewers sections where the heat exchangers can be installed can be seen in Figure 4.

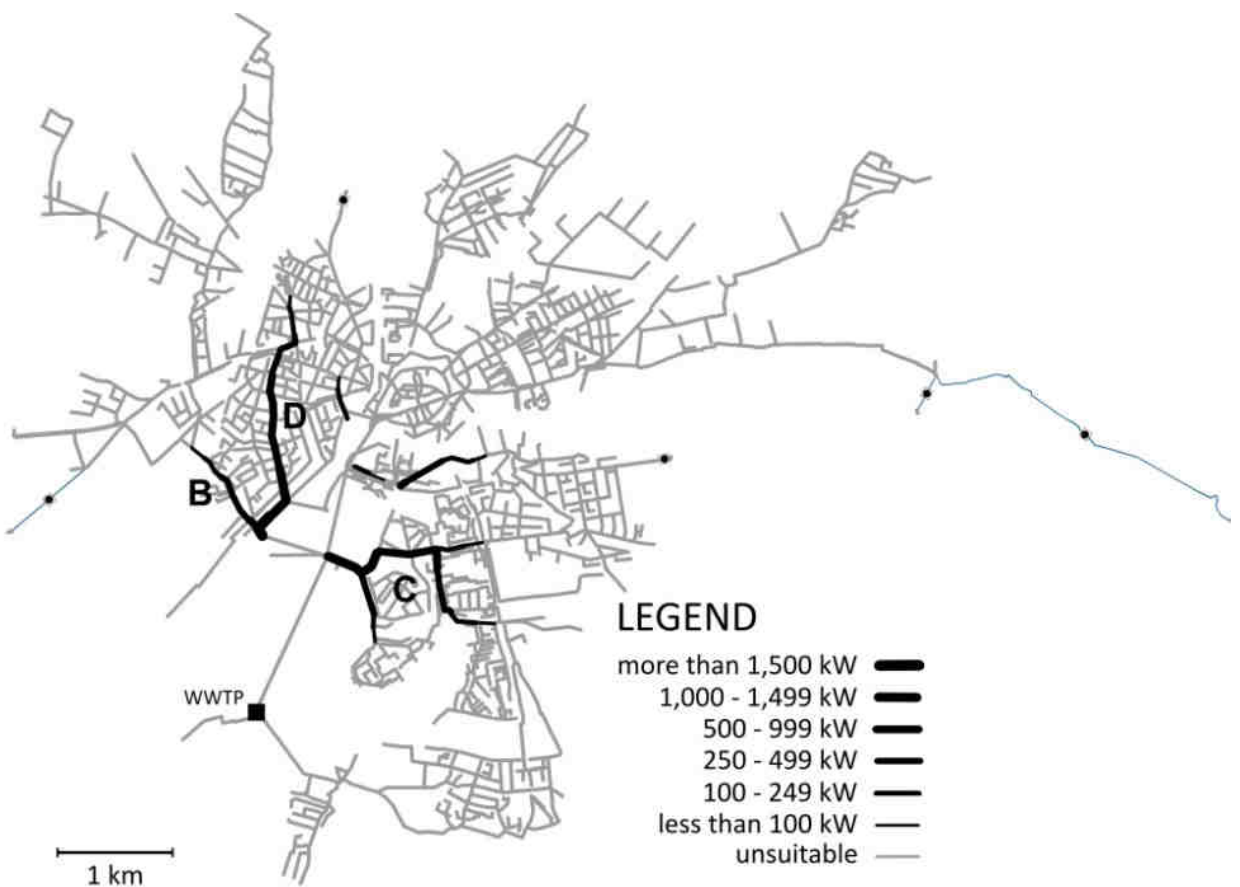

Fig. 4. Available power of the heat exchangers in the pilot catchment. The thickness of black line distinguishes the maximum potential power of the heat exchanger supposing it is installed in the upstream direction along the whole section

Classification of suitability of continuous sewer sections of the trunk sewers in the pilot catchment for the installation of heat exchangers and estimation of their potential power

\begin{tabular}{|c|c|c|c|c|c|}
\hline \multirow{2}{*}{\multicolumn{2}{|c|}{ Sewer }} & \multicolumn{2}{|c|}{ Total length $L[\mathrm{~m}]$} & \multirow{3}{*}{$\frac{\mathbf{P}_{W T}[\mathbf{k W}]}{4}$} & \multirow{3}{*}{$\begin{array}{c}\text { Installation potentia } \\
\text { no }\end{array}$} \\
\hline & & \multirow{2}{*}{$\begin{array}{c}\text { suitable } \\
0\end{array}$} & \multirow{2}{*}{$\begin{array}{c}\text { partly suitable } \\
7 \\
\end{array}$} & & \\
\hline $1 \mathrm{~A}$ & & & & & \\
\hline $\mathrm{B}$ & & 0 & 1073 & 563 & yes \\
\hline \multirow{5}{*}{$\mathrm{C}$} & $\mathrm{C} 1$ & 0 & 393 & 206 & yes \\
\hline & $\mathrm{C} 2$ & 70 & 814 & 501 & yes \\
\hline & C3 & 0 & 499 & 262 & yes \\
\hline & $\mathrm{C} 4$ & 0 & 725 & 381 & yes \\
\hline & $\mathrm{C} 5$ & 0 & 1167 & 613 & yes \\
\hline \multirow{5}{*}{$1 \mathrm{C}$} & $1 \mathrm{C} 1$ & 0 & 361 & 190 & yes \\
\hline & $1 \mathrm{C} 2$ & 0 & 967 & 508 & yes \\
\hline & $1 \mathrm{C} 3$ & 0 & 129 & 68 & no \\
\hline & $1 \mathrm{C} 4$ & 0 & 45 & 24 & no \\
\hline & $1 \mathrm{C5}$ & 0 & 34 & 18 & no \\
\hline $\mathrm{D}$ & & 484 & 2117 & 1620 & yes \\
\hline $\mathrm{D}+\mathrm{B}$ & & 22 & 23 & 35 & yes \\
\hline$E$ & & 66 & 291 & 222 & yes $^{1}$ \\
\hline
\end{tabular}

${ }^{1}$ section connected to upstream trunk sewers B and D with identified potential 
Maximum amount of heat recoverable from the whole sewer system depends on the admissible decrease of temperature at the WWTP inflow. A value of $0.5^{\circ} \mathrm{C}$ is considered the admissible drop of wastewater temperature still not affecting the WWTP efficiency $[12,16]$. This corresponds to the maximum possible installed power of the heat exchangers (about $700 \mathrm{~kW}$ ) providing heat of $16.3 \mathrm{TJ}$ per heating season, representing thus $2.2 \%$ of the total heat consumption in the pilot catchment.

\section{Discussion and conclusions}

The presented approach to the assessment of the theoretical heat recovery potential from wastewater in the sewer system is generally applicable, however, for other heat exchanger types and other climatic and economic conditions, values of the suitability criteria for the heat exchanger installation must be adapted.

The limiting value of the theoretical heat availability (set to $100 \mathrm{~kW}$ within the presented phase of the project) is subject to further investigation based on the discounted payback period analysis. First results show that if the heat consumer is close to a suitable sewer reach and costs of the new heat source connection are low, a heat exchanger with the power of $40 \mathrm{~kW}$ might be economically efficient.

An analysis of 50 city-owned buildings in the vicinity of suitable sewers identified 7 buildings that could be supplied by the power of $695 \mathrm{~kW}$ produced by heat exchangers and have the discounted payback period less than 10 years. Total annual savings were quantified to be 90,000 EUR.

Temperature and discharge characteristics in the individual sewers used for the identification of the theoretical heat recovery potential are biased by uncertainties as the monitoring and dry weather flow model calibration were performed only for the end profiles of the trunk sewers. Thus, every heat exchanger project should be preceded by a seasonal monitoring of temperatures and discharges at the installation site and their statistical evaluation. We recommend to determine also the shear stress in the sewer to get an idea of the expected biofilm amount and/or to test the cleaning strategy on in-situ biofilm samples grown on the same material like the heat exchanger.

\section{Acknowledgements}

Project "Heat recovery from wastewater in combined sewer systems" is supported by the Technology Agency of the Czech Republic (Project No. TA03020600). The simulation model was afforded by Hradec Kralove sewer system manager Vodovody a kanalizace Hradec Kralove, a.s. The heat exchanger was developed in cooperation with ATEKO, a.s.

\section{References}

[1] Lundie S, Peters GM, Beavis PC. Life cycle assessment for sustainable metropolitan water systems planning. Environ Sci Technol. 2004;38:3465-73. DOI: 10.1021/es034206m.

[2] Elías-Maxil JA, van der Hoek JP, Hofman J, Rietveld L. Energy in the urban water cycle: Actions to reduce the total expenditure of fossil fuels with emphasis on heat reclamation from urban water. Renew Sust Energy Rev. 2014;30:808-820. DOI: 10.1016/j.rser.2013.10.007.

[3] Racoviceanu AI, Karney BW, Kennedy CA, Colombo AF. Life-cycle energy use and greenhouse gas emissions inventory for water treatment systems. J Infrastruct Syst. 2007;13:261-70. DOI: 10.1061/(ASCE)1076-0342(2007)13:4(261). 
[4] US EPA. Performance ratings methodology for incorporating source energy use. USA: EPA/Energy Star. http://www.mass.gov/eea/docs/doer/energy-efficiency/epa-site-source-for-benchmark-dec-2007.pdf; 2011.

[5] Cheng CL. Study of the inter-relationship between water use and energy conservation for a building. Energy Build. 2002;34:261-266. DOI: 10.1016/S0378-7788(01)00097-4.

[6] Daigger GT. Evolving urban water and residuals management paradigms: Water reclamation and reuse, decentralization, and resource recovery. Water Environ Res. 2009;81:809-823. DOI: $10.2175 / 193864708790893378$

[7] Meggers F, Leibundgut $\mathrm{H}$. The potential of wastewater heat and exergy: Decentralized high-temperature recovery with a heat pump. Energy Build. 2011;43:879-886. DOI: 10.1016/j.enbuild.2010.12.008.

[8] Baek NC, Shin UC, Yoon JH. A study on the design and analysis of a heat pump heating system using wastewater as a heat source. Solar Energy. 2005;78:427-440. DOI: 10.1016/j.solener.2004.07.009.

[9] De Paepe M, Theuns E, Lenaers S, Van Loon J. Heat recovery system for dishwashers. Appl Therm Eng. 2003;23:743-756. DOI: 10.1016/S1359-4311(03)00016-4.

[10] Kahraman A, Çelebi A. Investigation of the performance of a heat pump using waste water as a heat source. Energies. 2009;2:697-713. DOI: 10.3390/en20300697.

[11] Wanner O. Wärmenutzung aus abwasser (Heat recovery from sewer systems). Schlussbericht Projekt Nr. 44177. Bern: Bundesamt Energie BFE. http://www.energieforschung.ch/; 2004.

[12] DWA. DWA - M114: Energie aus Abwasser - Wärme- und Lageenergie (Energy from Wastewater - Thermal and Potential Energy). DWA Hennef. http://www.dwa.de; 2009.

[13] Zogg M. History of heat pumps. Swiss contributions and international milestones. 9th Int IEA Heat Pump Conf. Zürich. Switzerland. IEA 1-16. http://www.zogg-engineering.ch; 2008.

[14] Kim J, Kim J, Kim J, Yoo C, Moon I. A simultaneous optimization approach for the design of wastewater and heat exchange networks based on cost estimation. J. Cleaner Prod. 2009;17:162-171. DOI: 10.1016/j.jclepro.2008.04.005.

[15] Czarniecki D, Pisarev V, Dziopak J, Słyś D. Technical and economic analysis of the application of the wastewater heat recovery system in an apartment building. Wrocław: Ofic Wyd Politechniki Wrocławskiej; www.eko-dok.p1/2014/13.pdf; 2014.

[16] Wanner O, Panagiotidis V, Clavadetscher P, Siegrist H. Effect of heat recovery from raw wastewater on nitrification and nitrogen removal in activated sludge plants. Water Res. 2005;39:4725-4734. DOI: 10.1016/j.watres.2005.09.026.

[17] Hvitved-Jacobsen T, Vollertsen J, Nielsen PH. A process and model concept for microbial wastewater transformations in gravity sewers. Water Sci Technol. 1998;37(1):233-241. DOI: 10.1016/S02731223(97)00774-9.

[18] Łagód G, Sobczuk H, Suchorab Z, Widomski M. Flow parameters effects on aerobic biodegradation of pollutants in sewer system. Ecol Chem Eng A. 2011;18(7):865-876. YADDA: bwmeta1.element.baztecharticle-BPG8-0061-0002.

[19] Łagód G, Sobczuk H, Suchorab Z, Widomski M. Advection-dispersion pollutant and dissolved oxygen transport as a part of sewage biodegradation model. Environ Prot Eng. 2009;35(3):305-317. http://epe.pwr.wroc.pl/2009/Lagod_3-2009.pdf.

[20] Wanner O. Warmeruckgewinnung aus Abwasser (Heat recovery from wastewater). Schriftenreihe der Eawag; 2009;19:62. http://library.eawag-empa.ch/schriftenreihe/schriftenreihe_19.pdf.

[21] Suchanek M, Vitek J, Stransky D, Kabelkova I, Finfrlova P. Drainage area study of the city of Hradec Kralove, Czech Republic, and its utilization for urban planning. GWF Int. 2013;154; 66-71.

[22] Characklis WG. Fouling biofilm development - A process analysis. Biotechnol Bioeng. 1981;23(9):19231960. DOI: 10.1002/bit.260230902.

[23] Bott TR. Fouling of Heat Exchangers. New York: Elsevier; 1995.

[24] Hvitved-Jacobsen T. Sewer Processes: Microbial and Chemical Process Engineering of Sewer Networks, Second edition. Boca Raton, London, New York, Washington: CRC PRESS; 2013.

[25] Wanner O. Biofilms Hamper Heat Recovery. Eawag News. 2006;60e:31-32. http://www.novaquatis.eawag.ch/services/publikationen/eanews/news_60/en60e_wanner_hamper_heat.pdf.

[26] Wilderer PA, Cunningham A, Schnidler U. Hydrodynamics and shear stress: Report from the discussion session. Water Sci Technol. 1995;32(8):271-272. DOI: 10.1016/0273-1223(96)00038-8.

[27] Ahyerre M, Chebbo G, Saad M. Sources and erosion of organic solids in a combined sewer. Urban Water. 2000;2:305-315. DOI: 10.1016/S1462-0758(01)00012-7.

[28] Banasiak R, Verhoeven R, De Suttera R, Tait S. The erosion behavior of biologically active sewer sediment deposits: Observations from a laboratory study. Water Res. 2005;39:5221-5231. DOI: 10.1016/j.watres.2005.10.011. 
[29] Ashley RM, Goodison MJ, Wotherspoon DJJ, McGregor I, Coghlan BP. The deposition and erosion of sediments in sewers. Water Sci Technol. 1992;26(5-6):1283-1293. http://wst.iwaponline.com/content/ 26/5-6/1283.

[30] Pisano WC, Barsanti J, Joyce J, Sorensen H. Sewer and tank sediment flushing: Case studies. Report EPA/600/R-98/157. Cincinnati, US EPA. https://www.epa.gov/nscep; 1998.

[31] Guzmán K, La Motta E, McCorquodale J, Rojas S, Ermogenous M. Effect of biofilm formation on roughness coefficient and solids deposition in small-diameter PVC sewer pipes. J Environ Eng. (Reston, VA, U. S.). 2007;133(4):364-371. DOI: 10.1061/(ASCE)0733-9372(2007)133:4(364).

[32] Kay JM, Nedderman RM. An Introduction to Fluid Mechanics and Heat Transfer. Cambridge: Cambridge University Press; 1975.

[33] Buri R, Kobel B. Energie aus Kanalabwasser - Leitfaden für Ingenieure und Planner (Energy from wastewater - Handbook for Engineers and Planners). Osnabrück/Bern: DBU; 2005. http://www.kasag.ch/LinkClick.aspx?fileticket=ruo3pbX3aXc\%3D\&tabid=94\&language=de-CH. 